\title{
RECENT GEOMORPHIC CHANGES AND ANTHROPOGENIC ACTIVITIES IN THE DELTAIC PLAIN OF PINIOS RIVER IN CENTRAL GREECE
}

\author{
Gaki-Papanastassiou K. ${ }^{1}$, Karymbalis E. ${ }^{2}$ and Maroukian H. ${ }^{1}$ \\ ${ }^{1}$ University of Athens, Faculty of Geology and Geoenvironment, Department of Geography and \\ Climatology, Panepistimioupolis, 15784 Athens, Greece. \\ Emails:gaki@geol.uoa.gr,maroukian@geol.uoa.gr \\ ${ }^{2}$ Harokopio University, Department of Geography, 70 El. Venizelou Str. 17671 Athens, Greece.
}

Email:karymbalis@hua.gr

\begin{abstract}
The Pinios river delta is a Late Holocene arcuate type delta, located in the southern Thermaikos gulf (Central Greece). In order to determine the processes which contributed in the recent configuration of the delta, a detailed geomorphic map at the scale of 1:5000 has been prepared showing both the deltaic plain and the coastal zone features using GIS techniques. Comparative examinations of aerial photographs taken in different dates and reliable maps of the last two centuries along with field observations depict recent changes of the delta morphology. The most important factors for the development of the delta are fluvial sedimentation, wave activity and longshore currents in a tectonically active area. Land uses throughout the delta plain have been mapped in an attempt to identify socio-economic activities. The dominant feature in the deltaic plain is the numerous abandoned meandering channels. The delta shoreline is generally retreating due to marine processes especially where former river mouths occur. Finally, various future sea-level rise scenarios have been analyzed and an assessment of the impacts of the potential global future sea-level rise to the delta is estimated.
\end{abstract}

Key words: coastal geomorphology, Pinios river delta, geomorphological mapping, Central Greece.

\section{Introduction}

A large part of the low lands of mainland Greece are composed of deltaic plains. The Pinios river delta is located in Central Greece in the southern Thermaikos gulf of the north-east Aegean Sea (Fig. 1). It is an arcuate type delta with an area of $69 \mathrm{~km}^{2}$ and a mean gradient of $0.058 \%$. According to the delta classification proposed by Galloway (1975), the Pinios delta should be classified among those dominated by fluvial sediment supply and wave activity. The combination of suitable conditions for delta formation led to the development of Pinios delta during Late Holocene. Weathering and erosion in the catchment area of the Pinios river has resulted in the production of large quantities of sediments available for transportation. In addition, climate conditions (high mean annual precipitation especially between November and February) and relatively favorable marine characteristics of the receiving basin resulted in the delta formation.

The aim of this study is to determine the processes which contributed in the recent configuration of the delta as well as to assess impacts of the potential future sea-level rise to the delta. 


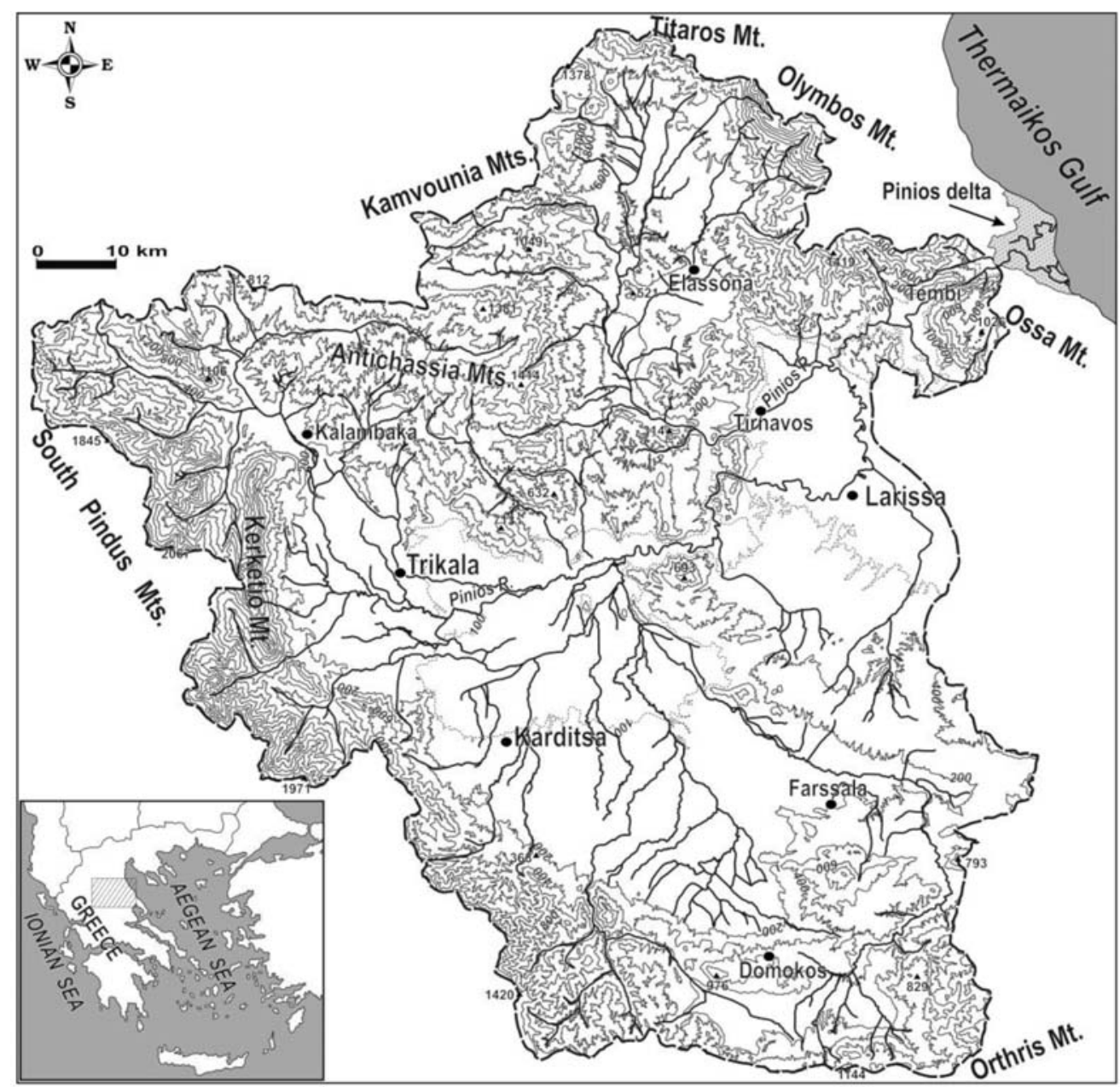

Fig. 1: Topographic map of the Pinios river drainage basin.

\section{Drainage basin}

The catchment basin of Pinios river has an area of $10704 \mathrm{~km}^{2}$ flowing into Thermaikos gulf (Fig. 1). Lithologically, it consists of $25,8 \%$ clastic sedimentary rocks, $21.4 \%$ metamorphic rocks, $7.1 \%$ calcareous sedimentary rocks, $5.5 \%$ igneous rocks and $40.2 \%$ of unconsolidated fluvial and lacustrine sediments (Fig. 2).

A large amount of riverine sediments has been trapped within the extensive alluvial plain of the river due to the presence of the narrow, hard to erode, gorge of Tembi located between the delta and the alluvial plain acting as a temporary base level for the whole drainage basin of Pinios river. This is the main reason for the limited extension of the delta in relation to the area of the drainage basin.

Mean annual precipitation ranges from $400 \mathrm{~mm}$ near the delta to nearly $1600 \mathrm{~mm}$ in the highlands (Table 1). Mean annual temperature is about $17^{\circ} \mathrm{C}$. Mean annual discharge is $81 \mathrm{~m}^{3} / \mathrm{sec}$ ranging between $11 \mathrm{~m}^{3} / \mathrm{sec}$ and $176 \mathrm{~m}^{3} / \mathrm{sec}$. The high water period lasts from December till April. Annual sus- 


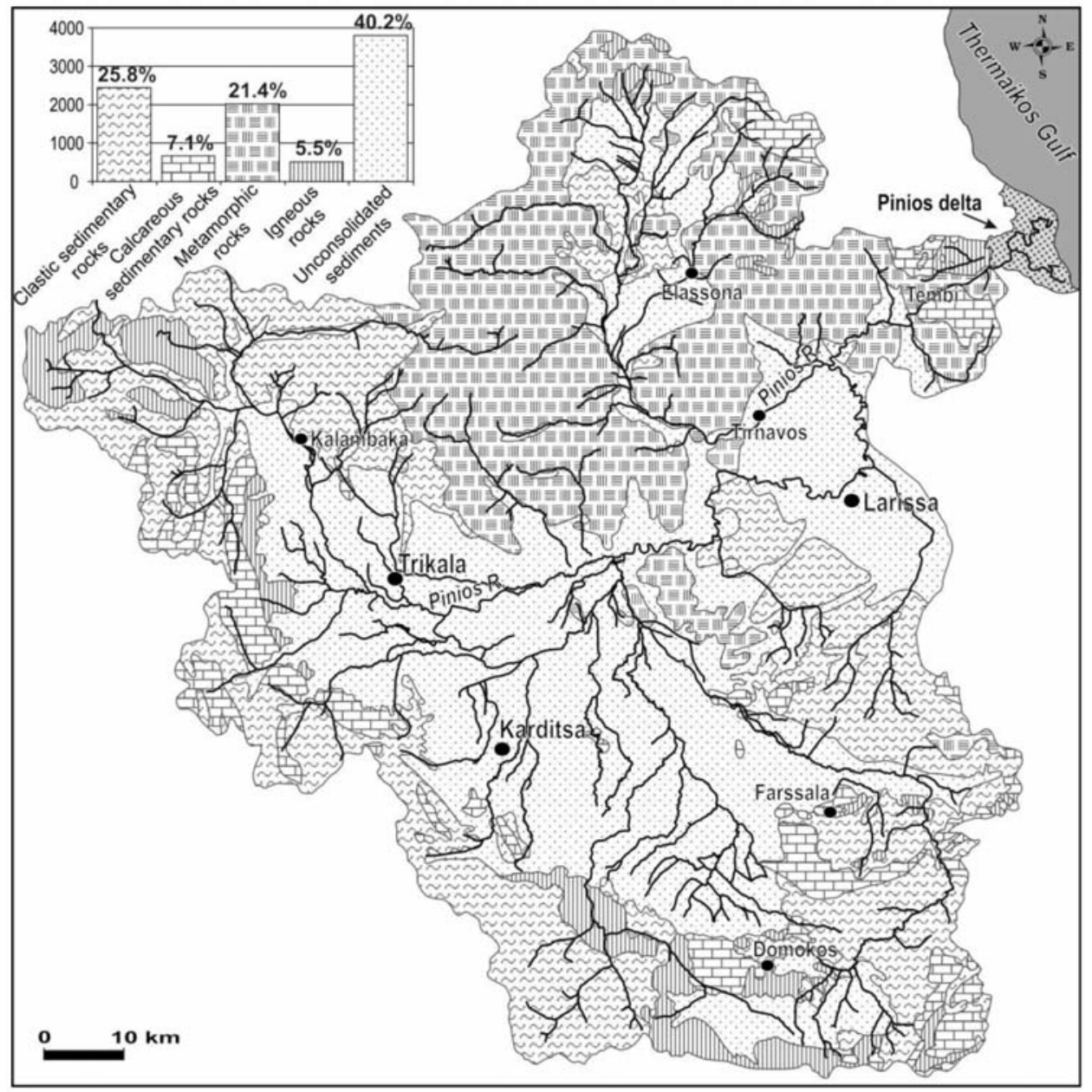

Fig. 2: Lithologic map of the Pinios river drainage basin with a diagram showing the participation of each one of the lithological types in the basin. It is based on the Greek Institute of Geology and Mineral Exloration (IGME) geological map of Greece (2006).

pended sediment load is estimated to be $0.6^{*} 10^{3} \mathrm{t} / \mathrm{km}^{2}$ while annual yield of dissolved load is $0.15^{*} 10^{3} \mathrm{t} / \mathrm{km}^{2}$ (Poulos et. al. 2000).

\section{Thermaikos Gulf: the receiving basin}

The Pinios delta is located on the western coast of south Thermaikos gulf (Fig. 3) having a microtidal marine environment (mean tidal range about $20 \mathrm{~cm}$ ) (Hydrographic Service of the Navy, 2005). Coastal drift is towards the south. Surface water circulation is influenced mainly by the prevailing wind conditions. Prevailing N-NW winds move waters south along the coastline while in the case of S-SW winds surface water moves northwards. Wave heights and direction depends on the existing wind regime. Waves related to southerly winds are considered to be the most important in terms of magnitude. Thus high waves of long wavelength are to be expected only from southerly directions. In contrast, winds blowing from the north are more frequent and despite the smaller fetches they gen- 


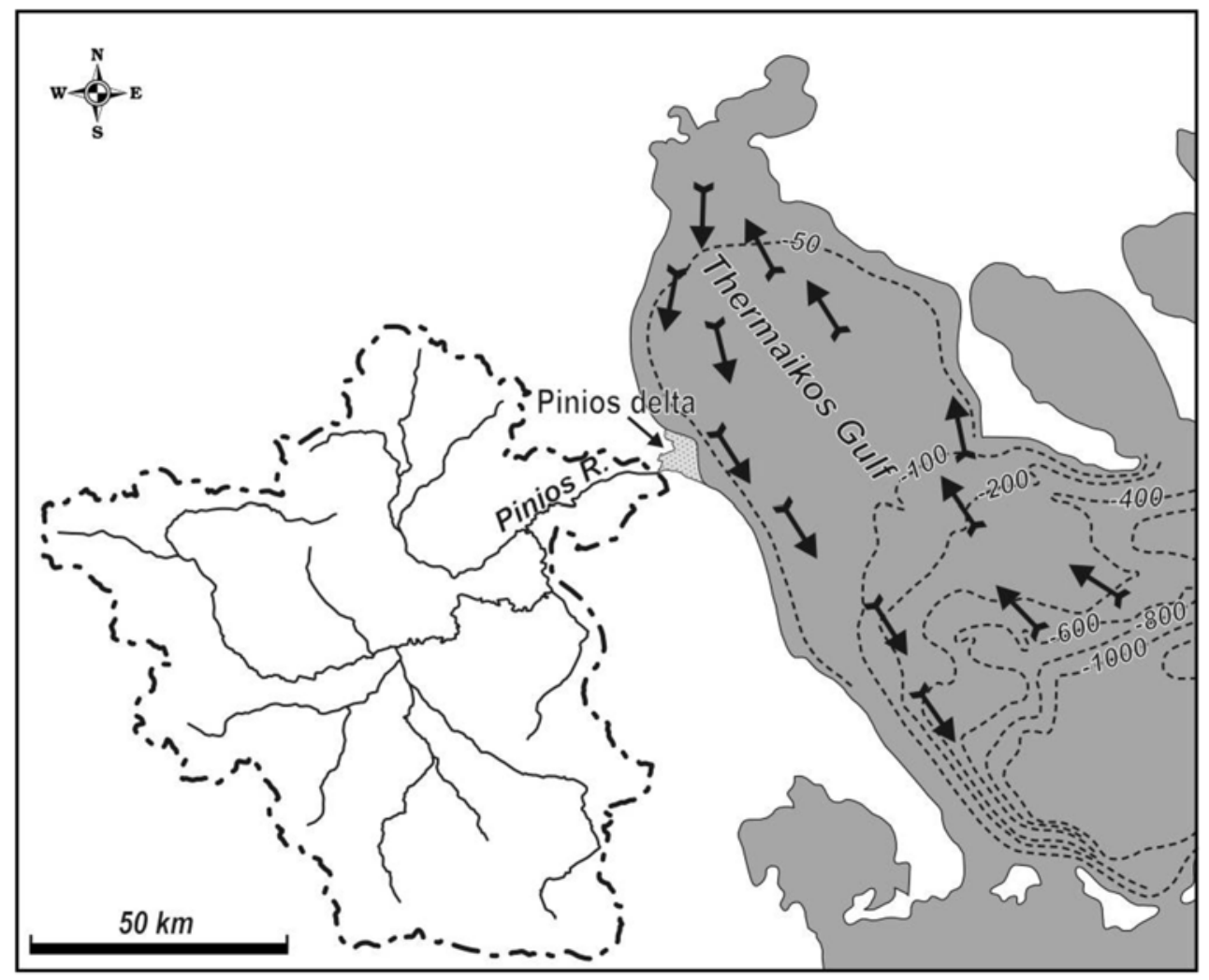

Fig. 3: Location map of the Pinios river drainage basin and delta. Arrows indicate surface waters circulation patterns of Thermaikos gulf.

erate surface gravity waves influencing the general water surface circulation of the gulf.

The Pinios delta is exposed to long wave fetches subjecting the deltaic coastline to a monthly wave power of $70-1454 \mathrm{w} / \mathrm{m} 2$ (Poulos et al. 2000). Current speeds are of the order of $5-20 \mathrm{~cm} / \mathrm{sec}$ near the water surface and up to $9 \mathrm{~cm} / \mathrm{sec}$ near the seabed.

\section{Methodology}

In this study topographic diagrams at a scale of 1:5.000 were used in the field to prepare a detailed geomorphological map depicting deltaic features in order to determine the dominant processes responsible for the configuration of the delta. Two series of aerial photographs taken in 1945 and 1995 at scales 1:42000 and 1:33000 respectively were used together with old maps of the previous century in an attempt to determine diachronic shoreline and channel changes along the Pinios river deltaic plain and the coastal zone.

One of the dominant factors for the future evolution of the delta is the expected global sea-level rise. The low-lying areas within the elevation zones of 0-0.5, 0-1, 0-2 and 0-4 m were calculated and land uses for these zones were defined and estimated. Land use were grouped in nine classes including complex cultivation patterns, discontinuous urban fabric, land primarily occupied by agriculture, coastal sands, broadleaf forest, natural grassland, shrub, sclerophyllous vegetation and non 


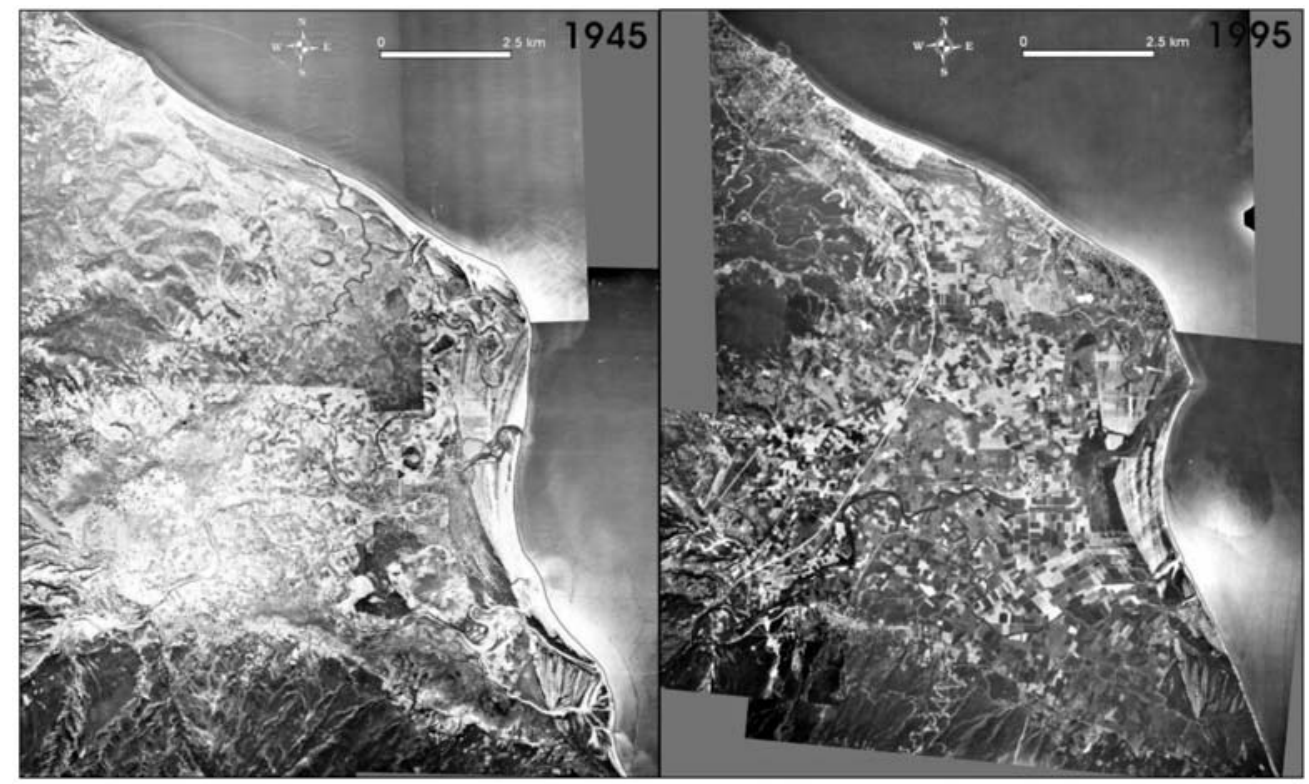

Fig. 4: Aerial photo-mosaic of the Pinios river delta of 1945 and 1995 respectively.

irrigated arable land. A spatial database from analogue maps at various scales, geometrically corrected aerial photographs and field-work data was prepared using GIS.

\section{Results}

The Pinios river delta is one of the few Greek deltas that have not been affected by human interference like channel alignment or diversion. Abandoned meander channels and oxbow lakes are visible in 1945 aerial photographs (Fig. 4 and 5).

The most recently abandoned distributary is the meandering channel south of the present active one leading to Armira about $4 \mathrm{~km}$ south of the present active mouth of the river (Fig. 6a and 5). This channel, which is depicted in 1881, 1910, 1924 and 1935 accurate topographic maps, was partially abandoned naturally in 1955 when the river migrated northwards. Comparable observations of the 1945 and 1995 aerial photographs show that the new course of the active river channel follows a previous abandoned path. A much older group of abandoned channels is located at the northern end of the delta.

The Pinios river deltaic coastal zone is dominated by the abundance of medium to coarse sandy sediments (Fig. 6b). The deltaic coastline has advanced by the gradual accretion of beach ridges. The period of high water discharge (December to March) coincides with that of high wave power. Hence the fluvial sediment input is being reworked by waves and associated longshore currents to form a series of beach ridges (Fig. 6d). At least six beach ridge generations presenting different orientation were recognized and mapped (Fig. 5).

The observation of the georeferenced aerial photographs and the comparable analysis of the digitized shorelines during the period 1945-1995 show that the coastline along the delta south of the present 


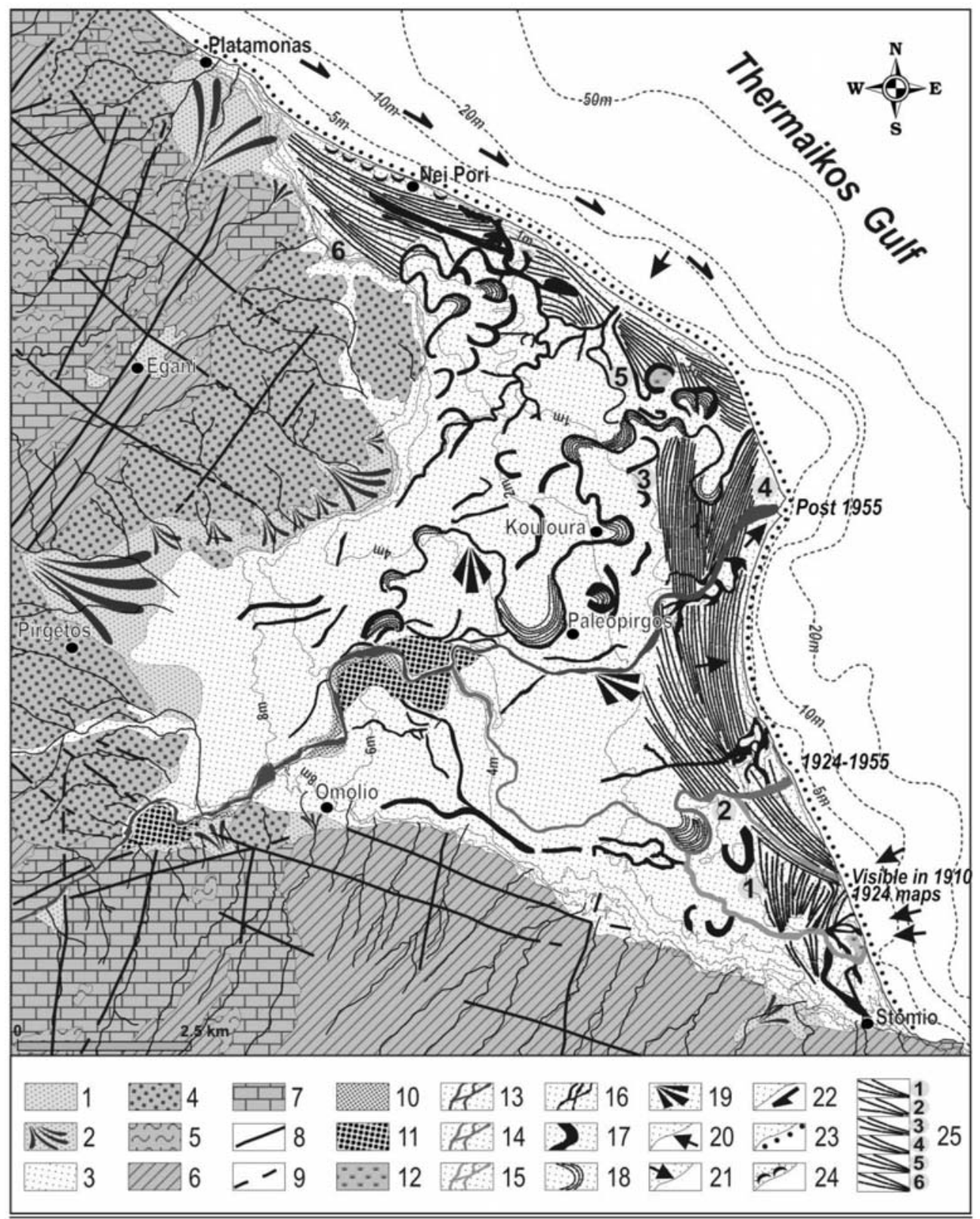

Fig. 5: Geomorphological map of the Pinios river delta. The map was prepared at the scale of 1:5000 based on field observations and the interpretation of aerial photographs. Legend: 1. Alluvial deposits, 2. Alluvial cones, 3. Deltaic plain deposits, 4. Neogene formations 5. Flysch, 6. Schists, gneiss, Amphibolites, 7. Marbles - limestones, 8. Visible fault, 9. Probable fault, 10. Lower fluvial terrace, 11. Higher fluvial terrace, 12. Coastal marsh, 13. Recent channel (active after 1955), 14. Channel before 1955, 15. Channel visible in 19101924 maps, 16. Abandoned channels, 17. Abandoned channels, 18. Point bars, 19. Crevasse splays, 20. Retreating coastline, 21. Prograding coastline, 22. Longshore currents, 23. Sandy beaches, 24. Coastal dunes, 25 . Beach ridge groups. 

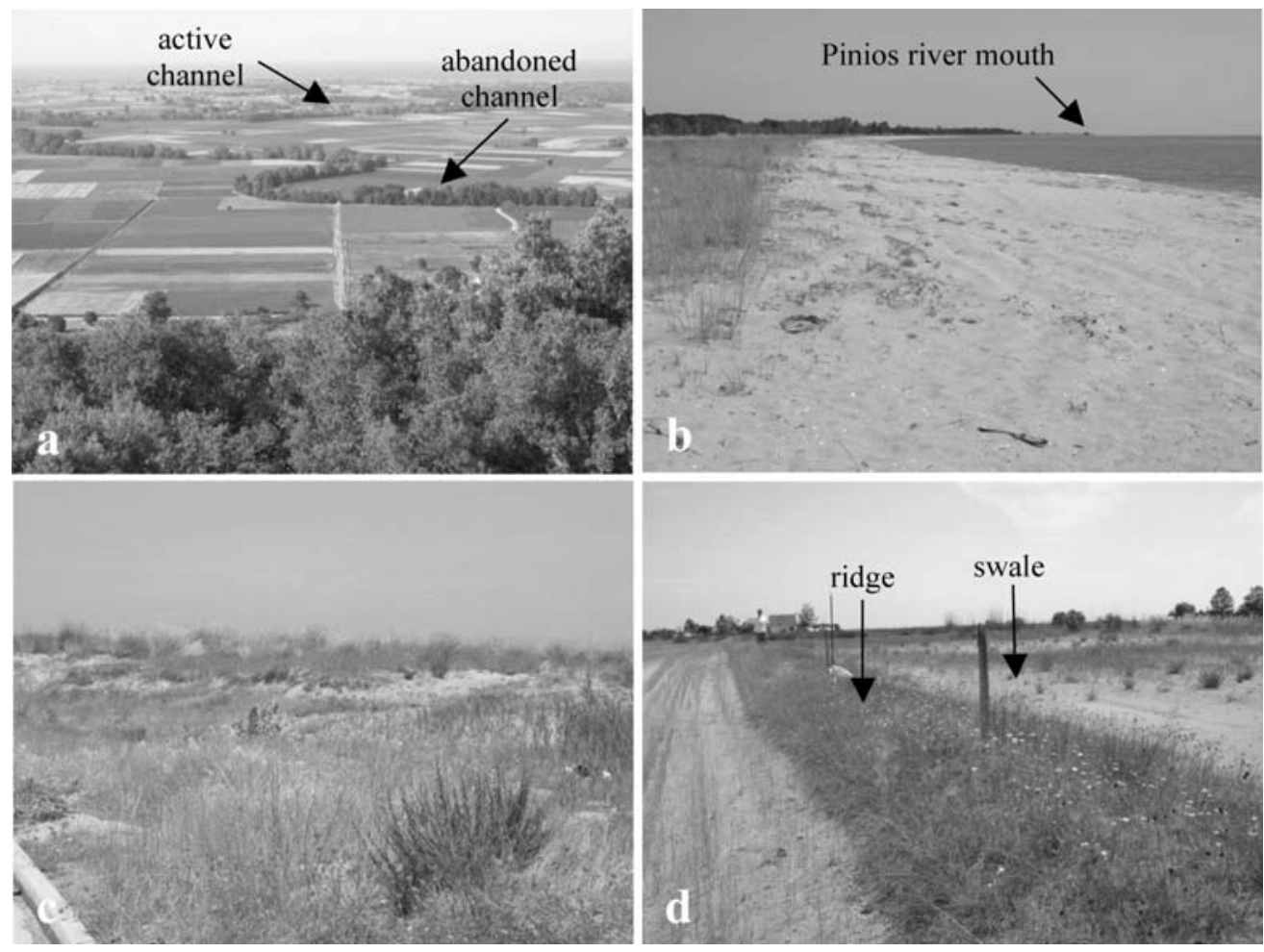

Fig. 6: a) Abandoned and active channel in the deltaic plain of Pinios river. b) Prograding sandy coast near the mouth of Pinios river. c) coastal dunes near Nei Pori. d) ridge and swale topography.

mouth has advanced through beach ridge accretion. The area around the mouth has prograded for about $440 \mathrm{~m}$ from 1955 to 1995 (11 m/yr) when the river shifted to its present position. On the contrary, the area of the abandoned mouth to the south (north of Stomio) has retreated for about $180 \mathrm{~m}$ corresponding to a maximum erosion rate of $4 \mathrm{~m} / \mathrm{yr}$ for the 40 year period between 1955 and 1995 .

A hazard that is expected to influence the Pinios delta like most of the low-lying coastal areas is the anticipated rapid sea-level rise (Gaki-Papanastassiou et al. 1997). The recent IPCC (2007) reports suggest that sea level will rise from 20 to $50 \mathrm{~cm}$ by the year 2100 . In the case of deltaic deposits, an additional land subsidence due to sediment compaction should be taken into account. This future sealevel rise will have negative consequences for low-lying deltaic formations (Maroukian and Karymbalis 2004; Karymbalis et al. 2007, Karymbalis and Gaki-Papanastassiou 2008).

Such a rise could enhance the retreat of the Pinios delta coastline. The lying below the contour line of $0.5 \mathrm{~m}\left(6.5 \mathrm{~km}^{2}\right.$ ) corresponds to $9.5 \%$ of the total area of the delta will face severe problems (Fig. 7). Furthermore, the low-lying area below $1 \mathrm{~m}$ is $14.8 \mathrm{~km}^{2}$ corresponding to $21.4 \%$ of the delta. It is estimated that an extensive part of the low-lying deltaic coastal zone is occupied by economically important cultivations $\left(4.2 \mathrm{~km}^{2}\right.$ below $0.5 \mathrm{~m}$ and $8.8 \mathrm{~km}^{2}$ below $\left.1 \mathrm{~m}\right)$. The Pinios delta hosts some of the most productive agricultural lands of the broader area. In the early 50's the only settlements along the coast were Platamonas in the north and Stomio in the south. In recent decades these regions have expanded considerably as they have became important resort areas for local and foreign tourists. The most important resort settlement today is Nei Pori southeast of Platamonas. 


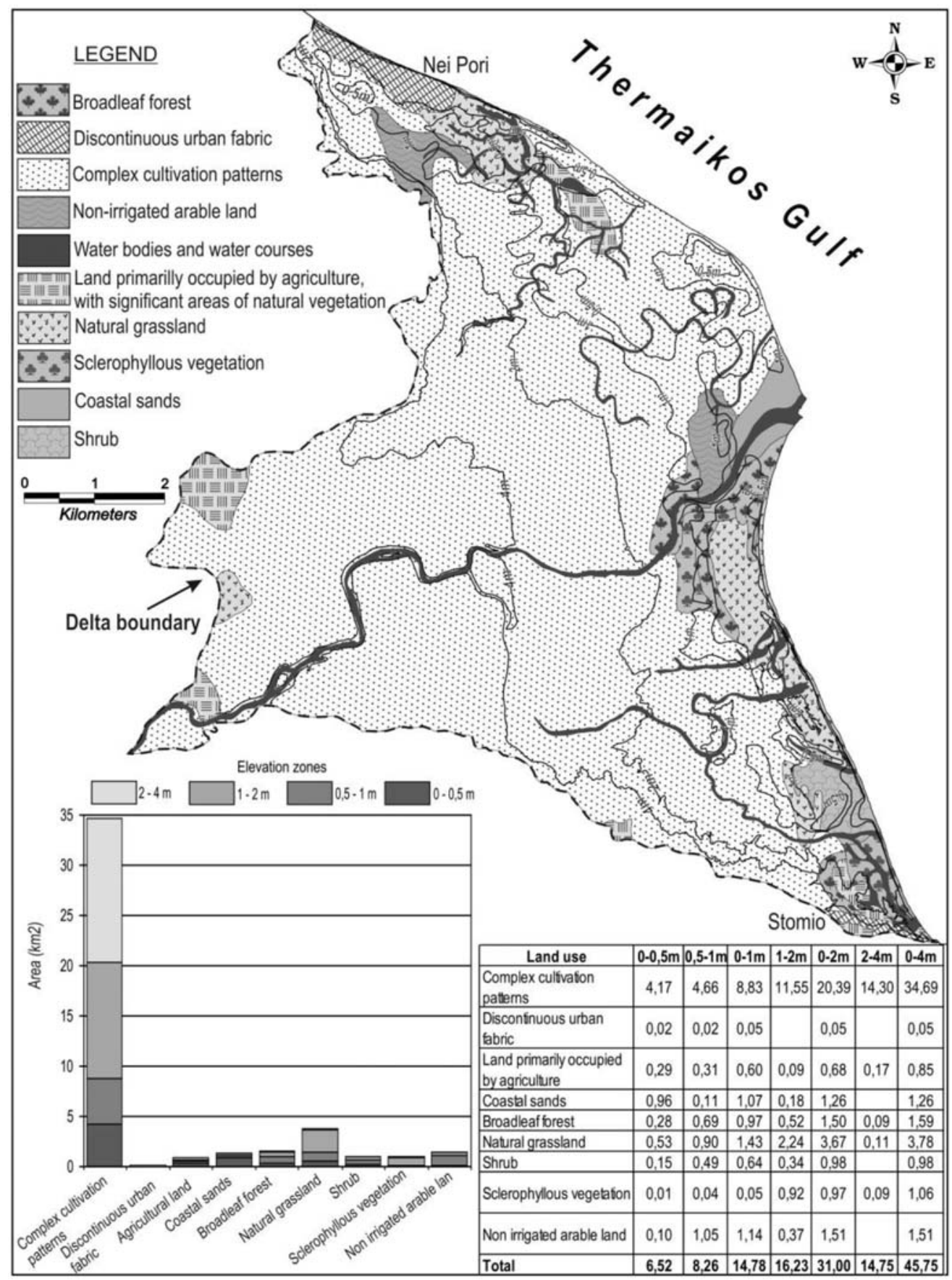

Fig. 7: Map portraying land use of the low-lying area of the delta. The table includes the area of each land use category for each elevation zone (in $\mathrm{km}^{2}$ ) and the diagram shows the distribution of the nine land use classes for each elevation zone. 


\section{Concluding Remarks}

- The evolution and the associated morphology of the deltaic plain and coastline results mainly from interaction between the water/sediment discharge and the prevailing wave activity. Abandoned meander channels and beach ridges are the dominant delta landforms. The river has changed its course several times in recent times.

- The region where the delta progrades today is the area around the present mouth where the maximum progradation rate is observed (11 m/yr is estimated between 1955 and 1995) as well as south of it. For the same time period a retreat rate of $4 \mathrm{~m} / \mathrm{yr}$ is estimated north of Stomio where the most recent abandoned mouth is being reworked by marine processes since 1955 .

- An increase in mean sea-level by more than $0.5 \mathrm{~m}$, related to a total increase of $2-3^{\circ} \mathrm{C}$ of air temperature might cause severe erosion, with important economic repercussions. It is estimated that approximately $45.75 \mathrm{~km}^{2}$ of the deltaic plain lies below the $4 \mathrm{~m}$ contour line with $14.8 \mathrm{~km}^{2}$ located below the absolute elevation of $1 \mathrm{~m}$ while the area expected to be covered by the end of this century with a $50 \mathrm{~cm}$ sea-level rise is $6.5 \mathrm{~km}^{2}$. A large part of the potential area to be permanently flooded and/or eroding is occupied by economically important agricultural land and tourist activities.

\section{References}

Gaki-Papanastassiou, K., Maroukian, H., Pavlopoulos, K. and Zamani, A., 1997. The implications of the expected sea level rise on the low lying areas of continental Greece in the next century. Proceedings International Symposium on Engineering Geology and the Environment, Athens, 121-126.

Galloway, W.E., 1975. Process framework for describing the morphological and stratigraphic evolution of deltaic depositional systems. In: Broussard M. L. (Ed.): Deltas, Models for Exploration. Houston Geol. Soc., Houston, 87-98.

Hydrographical Service of the Navy, 2005. Tides and tidal data for Greek harbours, $4^{\text {th }}$ edition, Athens (in Greek).

Institute of Geology and Mineral Exploration of Greece (IGME) 2006. Geological map of Greece, scale 1:500000.

IPCC 2007. Climate Change 2007: The physical Science Basis Summary for Policymakers Contribution of Working Group I to the Fourth Assessment Report of the Intergovernmental Panel on Climate Change, Richard Alley, Terje Berntsen, Nathaniel L. Bindoff, Zhenlin Chen, Amnat Chidthaisong, Pierre Friedlingstein, Jonathan Gregory,Gabriele Hegerl, Martin Heimann, Bruce Hewitson, Brian Hoskins, Fortunat Joos, Jean Jouzel, Vladimir Kattsov, Ulrike Lohmann, Martin Manning, Taroh Matsuno, Mario Molina, Neville Nicholls, Jonathan Overpeck, Dahe Qin, Graciela Raga, Venkatachalam, Ramaswamy, Jiawen Ren, Matilde Rusticucci, Susan Solomon, Richard Somerville, Thomas F. Stocker, Peter Stott, Ronald J. Stouffer, Penny Whetton, Richard A. Wood, David Wratt, Geneva, 18 pp.

Karymbalis, E., Gaki-Papanastassiou, K. and Maroukian, H., 2007. Recent geomorphic evolution of the fan delta of the Mornos river, Greece: Natural Processes and Human Impacts. Bulletin of the Geological Society of Greece. Proceedings of the $11^{\text {th }}$ International Congress, vol. XXXX, 1538-1551.

Karymbalis, E. and Gaki-Papanastassiou, K., 2008. Geomorphological study of the river deltas of Pinios, Kalamas, Evimos and Mornos. Proceedings of the $4^{\text {th }}$ Panhellenic Conference on Coastal Zones Management, Mytilene, Greece, 86-94.

Maroukian, H and Karymbalis, E., 2004. Geomorphic evolution of the fan delta of the Evinos river in western Greece and human impacts in the last 150 years. Zeitschrift für Geomorphologie N.F., 48(2), 201-217.

Poulos, S., Chronis, G., Collins, M. and Lykousis, V., 2000. Thermaikos Gulf coastal system, NW Aegean Sea: an overview of water/sediment fluxes in relation to air-land-ocean interactions and human activities. Journal of Marine Systems, 25, 47-76. 